\title{
Analysis of the Current Situation of Teaching Management in Colleges and Universities and the Countermeasures to Improve the Quality of Teaching Management in Colleges and Universities
}

\author{
Weiwei Cui \\ Yancheng Teachers University, Yancheng, China \\ Email:wlaqer1314@sina.com
}

How to cite this paper: Cui, W. W. (2020). Analysis of the Current Situation of Teaching Management in Colleges and Universities and the Countermeasures to Improve the Quality of Teaching Management in Colleges and Universities. Open Journal of Social Sciences, 8, 64-70.

https://doi.org/10.4236/jss.2020.87006

Received: June 4, 2020

Accepted: July 10, 2020

Published: July 13, 2020

Copyright $\odot 2020$ by author(s) and Scientific Research Publishing Inc. This work is licensed under the Creative Commons Attribution International License (CC BY 4.0).

http://creativecommons.org/licenses/by/4.0/

\begin{abstract}
With the continuous innovation and development of the teaching system, China's education system is also constantly improving. Teaching management has always been the focus of education and teaching. This paper will focus on the analysis of the problems existing in the teaching management of colleges and universities in China, put forward countermeasures and methods to improve the quality of teaching management in colleges and universities, elaborate on the significance of improving the quality of teaching management in colleges and universities, and thereby promoting the sustainable and healthy development of college education and teaching.
\end{abstract}

\section{Keywords}

Colleges and Universities, Teaching Management, The Current Situation, The Countermeasures

\section{Introduction}

Teaching management is a process in which the principles and methods of management science and teaching theory are applied to give full play to the management functions of planning, organization, coordination and control, and all the elements of the teaching process are coordinated to make it run in an orderly manner and improve the efficiency (Lu, 2013). Teaching management serves for teaching, efficient and orderly teaching management creates a good environment 
and atmosphere for teaching, gives full play to the subjective initiative of teachers and students in the teaching process, and lays a foundation for achieving teaching objectives and completing teaching tasks. In college education, teaching and management have close relations, the organization and management of the teaching process, the division and cooperation of labor of the teaching management personnel, the connection between the teaching links, the arrangement and implementation of the teaching plan and the teaching syllabus, etc., must be carried out according to the characteristics of the teaching activities, teaching cannot be separated from management, and management is the basis and guarantee of the implementation of teaching. With the continuous development of education, China's colleges and universities expand enrollment greatly, which gradually put strains on all kinds of educational resources, there are also a series of problems in teaching management, and how to improve the quality of teaching management has become a major practical problem that China's colleges and universities are generally concerned and thinking about.

\section{The Problems of Teaching Management in Colleges and Universities in China}

\subsection{The Concept of Teaching Management Is Obsolete and the Trend of Administrative Management Is Serious}

In the process of the continuous reform and development of China's society, "people-oriented" is an indispensable and important content, which is of great significance and value to the improvement of the management effect and level of higher education (Xu, 2019). However, the concept of teaching management in Chinese universities is still backward, and the management concept of "peopleoriented" has not been truly established. There are serious trends in experience management and administrative management. First of all, teaching managers always dominate the work of making teaching plans, supervising teaching process and evaluating teaching results, while teachers and students, as objects of teaching management, seldom participate in teaching management. Secondly, administrative teaching management pays one-sided attention to the formulation of students' behavioral norms and ignores the importance of positive education. Students are prone to antagonism, which is not conducive to the construction of a harmonious teacher-student relationship and seriously affects the teaching quality of schools. Moreover, too much emphasis on administrative management and neglecting academic creation tend to foster the impetuous atmosphere, which is not conducive to the formation of a good atmosphere for learning.

\subsection{The Overall Structure and Quality of University Teaching Management Team Are Not Perfect}

The overall structure and quality of the teaching management team will greatly affect the level of teaching management in colleges and universities. At present, relevant departments in colleges and universities have been treating teaching 
management simply as the organizing the arrangement of curriculum schedule, arranging teaching task, setting training plan and managing make-up examination and retake courses and other concrete teaching activities, and it ignores the overall structure and quality of the teaching management team, leading to the imperfection of the human resources construction of teaching management team, and it is mainly manifested in the following:

\subsubsection{The Professional Level of Teaching Administrators Is Insufficient}

At present, the organization structure of teaching administrative personnel in colleges and universities is complex, with fresh graduates without sufficient experience, cadres who have changed job mid-career, teachers who lack management knowledge and ability, etc., good and evil people mix up, teachers have different levels lacking of systematic and effective training, and the teaching management team as a whole lacks a higher level of professional skill. As a result, the strength of the teaching management will be relatively weak (Yang, 2019). In addition, due to the backward concept of management personnel, the new situation of the development and changes in teaching cannot be updated and improved in time, which not only affects the progress of education and teaching management, but also restricts the penetration of "people-oriented" teaching management concept.

\subsubsection{The Neglect of the Status of Teaching Administrators}

Teaching secretary is the grass-roots team in teaching management, also an important part of the university management team, but they are often ignored. The content of university teaching secretary work is very tedious, and they need to contact with a wide range of departments, both serving students and teachers. It is a typical service work in the university (Yang, 2019). Nowadays, teaching secretary positions generally have the problems of complicated work and large amount of tasks. The workload is not proportional to the gains, and the salary is less. According to the investigation of the author, the average salary of a teaching secretary is $¥ 4.8 \mathrm{~K} /$ month, which is not conducive to the development of teaching secretaries in colleges and universities from the economic perspective. Secondly, colleges and universities pay more attention to the development of professional teachers and neglect the cultivation of the work and quality of teaching secretaries. Teaching secretaries are often not recognized by superior leaders and get fewer opportunities for learning and communication. They tend to have a sense of burnout and a low sense of self-efficacy, which affects work efficiency (Liu, 2020).

\section{How to Improve the Quality of University Teaching Management}

\subsection{Truly Implement the "People-Oriented" Teaching Management Concept}

The traditional management concept of colleges and universities blindly pursues 
"giving people fish", ignoring the students' subjective initiative and creativity, depriving the students of their rights as learning subjects, and the modern teaching management concept of "people-oriented" has not been put into practice. Teaching management should always adhere to student-centered, give full play to the initiative of students, proceed from the individual characteristics and needs of students, constantly promote the democratization of education and teaching, enhance students' self-consciousness and subject consciousness, improve the ability of self-regulation. At the same time, school teachers should also actively implement the teaching concept of "people-oriented". In teaching, teachers should train students according to the characteristics of students' development, and make sure that teaching students in accordance with their aptitude and taking students as the center. Firstly, teachers should respect students' dominant position in learning, treat students fairly and justly, respect students' differences, and make students' personalities fully developed. Secondly, teachers should innovate teaching methods, create interesting teaching situations and create a relaxed and lively learning atmosphere. Furthermore, teachers should change their roles from imparting knowledge to guiding students' learning. They should pay attention to teacher-student interaction in class, guide students to learn and think, and provide students with space for active development.

\subsection{We Should Constantly Promote the Innovation of Teaching Management System and Improve the Operation Mechanism of Teaching Management}

Perfect system and well-established mechanism are the key and guarantee to improve the quality of teaching management. With the advent of the information age, higher education has entered a new stage of development. Colleges and universities should keep up with the pace of The Times, complete the reform and innovation of the teaching management system, strive to consciously promote the operation of the teaching management mechanism, and rectify and improve the contents, objectives, forms and other aspects of management. On the basis of drawing lessons from the experience of other colleges and universities, we need to combine with our own situation, reflect and summarize carefully, find out the defects and deficiencies in the management operation, constantly enrich the teaching management content and the teaching management connotation and standardize the teaching management. At the same time, we should vigorously promote the incentive system for managers, the system of rewards and punishments for assessment, the system of supervision, etc., so as to meet the demand, give consideration to fairness, and promote the development of education and teaching.

\subsection{We Should Strengthen the Teaching Management Team in Colleges and Universities, and Raise the Professional Level of the Teaching Management Team}

All colleges and universities should strengthen the ideological construction, con- 
sciously put the teaching management work in an important position, connect with education thought and the idea in a new era, base on the education modernization, establish the innovation consciousness, the challenge consciousness and the competition consciousness, strive to enhance the efficiency and institutionalization of teaching management work, and focus on the key and difficult point in management work.

In terms of talent management, the university should not only focus on mining outstanding teaching and research personnel, but also provide professional guidance and planning for education and teaching; Moreover, we should be good at absorbing the knowledge talents of teaching management, integrating them into the original management system, and combine the basic theories of teaching management with the construction of school's major, so as to promote the progress and development of school management. At the same time, colleges and universities should also pay attention to the professional and systematic training of managers, cultivate the consciousness of innovation, advocate inquiry learning, independent learning and cooperative learning, and strive to make the teaching management team grow and develop, making it play an important role in the management work. In addition, teaching management workers should also pay attention to strengthen their own construction, do their own work well, improve their ideological understanding, constantly improve their working methods, improve their own professional level and management ability, and make contributions to the school's management career.

\subsection{We Should Vigorously Strengthen the Regulatory Mechanism and Actively Carry out Feedback and Evaluation Work}

In the past process of teaching evaluation, due to the influence and restriction of traditional concepts, the effect of teaching evaluation could not be played effectively and the teaching evaluation remains on the surface. Strengthening teaching assessment and teaching evaluation is an important way to improve the quality of teaching management. Universities should set up relevant departments, select the appropriate management personnel supervision group or committee, adopt methods and means to evaluate, examine and give feedback to all levels and types of teaching management work timely and regularly with objective, fair and rigorous attitude, be able to recognize the outstanding achievements in work, be good at finding problems and shortcomings and point out the direction for improvement.

\subsection{Rationally Implement the Incentive Mechanism and Strive to Create a Competitive and Innovative Atmosphere}

The incentive mechanism is one of the important management mechanisms to mobilize teachers' enthusiasm in teaching and education and to tap their work potential ( $\mathrm{Li} \& \mathrm{Li}, 2019$ ). Blindly pursuing sternness will only kill enthusiasm, and in the teaching management we should attach importance to incentives and rewards. However, motivation should not be confined to the material level. In- 
stead, we should establish a comprehensive and multi-level incentive system of material, spirit, individuality and team to embody the scientific, competitive and systematic nature of the incentive system. Teaching management should follow the norms of behavioral science, understand and meet the reasonable needs of both teachers and students in the teaching process, so as to promote the realization of teaching objectives. In addition, the school should pay special attention to the encouragement and care for teaching management staff's. In terms of physical facilities, we should create a good office environment, equipped with advanced office equipment and network management system; In terms of job benefits, we should set up special allowances for teaching management positions, combine spiritual rewards with material rewards, establish a standard and effective reward system, and strive to create an atmosphere in which everyone strives to be the first.

\section{The Significance of Improving the Quality of Teaching Management}

Schools are the cradle of training talents, and the realization of national educational purpose needs to rely on the education and teaching work of schools. Improving the quality of teaching management is an important goal of school education and teaching.

With the continuous development of the productive forces, China's higher education is also moving forward step by step, facing new problems and challenges. Colleges and universities should find out the shortcomings of teaching management in time, adjust and improve it earnestly, and give full play to the spirit of innovation, so as to inject new strength and source into teaching management work and improve the quality of teaching management. Only in this way can we constantly promote higher education to adapt to the social economy and the development of The Times, better practice China's education policy, achieve the goal of the development of China's educational cause, and cultivate useful talents for the country.

In terms of the construction and development of colleges and universities, the developing and improving of the teaching management quality in colleges and universities are not only conducive to improving the strength of the teaching management team in colleges and universities, improving the professional level of the teaching management team, but also conductive to the integration and optimization of teaching and education resources, promotes the development and construction of universities, provides strong knowledge, technology and talent support for the rapid development of China's economy and society, and contributes to the development of China's education.

\section{Conclusion}

To sum up, college teaching management is an overall, comprehensive and systematic project, therefore, college should firmly establish a people-oriented teach- 
ing management philosophy, centered on students, teachers, managers, through setting up the education teaching management target, optimizing education teaching management system and improving the educational and teaching management mechanism in colleges and universities, to create a harmonious, stable, democratic management environment and promote the development and progress of teaching career. In addition, this paper also has some shortcomings in the research of teaching management in colleges and universities. For example, the theoretical level of discussing teaching management method is not mature enough. In addition to the use of theoretical analysis research methods lack of practical data investigation, it is necessary to explore and deepen the research on this topic further.

\section{Conflicts of Interest}

The author declares no conflicts of interest regarding the publication of this paper.

\section{References}

Li, Z. J., \& Li, Y. H. (2019). Human-Oriented Promotion of Teaching Management Innovation in Higher Education. Modern Communication, 15, 178-179.

Liu, Q. (2020). Current Situation of Teaching Secretary in Higher Vocational Colleges and Suggestions for Improvement. Fire Cracker Ball Technology and Market, 2, 234-235.

Lu, X. W. (2013). Advanced Dictionary of Management. Shanghai: Shanghai Lexicographical Publishing House.

Xu, X. Y. (2019). Analysis of Higher Education Teaching Management Mode Based on People-Oriented Concept. Education Science \& Culture Magazine (The Ten-Day Issue), $8,22-23$.

Yang, H. B. (2019). Analysis on Improving the Work Efficiency of College Teaching Secretaries in the New Era. Office Business, 8, 80-81. 